\title{
Effects of different sterilization methods of herbal formula on phytochemical compounds and antibacterial activity against mastitis-causing bacteria
}

\author{
Dian Wahyu Harjanti1 ${ }^{(\mathbb{D}}$, Fajar Wahyono ${ }^{1}$ and Vincentia Rizke Ciptaningtyas ${ }^{2}$
}

1. Department of Animal Science, Faculty of Animal and Agricultural Sciences, Diponegoro University, Semarang, Central Java, Indonesia; 2. Department of Clinical Microbiology, Faculty of Medicine, Diponegoro University, Semarang, Central Java, Indonesia.

Corresponding author: Dian Wahyu Harjanti, e-mail: harjantidian@gmail.com

Co-authors: FW: fjrwahyono@gmail.com, VRC: ciptaningtyas_vr@fk.undip.ac.id

Received: 02-01-2020, Accepted: 05-05-2020, Published online: 25-06-2020

doi: www.doi.org/10.14202/vetworld.2020.1187-1192 How to cite this article: Harjanti DW, Wahyono F, Ciptaningtyas VR (2020) Effects of different sterilization methods of herbal formula on phytochemical compounds and antibacterial activity against mastitis-causing bacteria, Veterinary World, 13(6): 1187-1192.

\begin{abstract}
Background and Aim: The current phytobiotic industry is struggling to determine a proper sterilization method for an herbal formula that comprises multiple plant extracts. Hence, this study aims to investigate the effects of two sterilization methods of herbal formula on phytochemical compounds and antibacterial activity against mastitis-causing bacterial isolates.

Materials and Methods: The herbal formula comprised the extracts of Piper betle leaves, Curcuma domestica, and Curcuma zanthorriza. We applied two sterilization methods - sterilization using $0.45 \mu \mathrm{M}$ syringe filter and sterilization using an autoclave at $121^{\circ} \mathrm{C}$ for $15 \mathrm{~min}$. After sterilization, we measured phytochemical contents (phenol and flavonoid) of the herbal formula. Using the disk diffusion method, the antibacterial susceptibility test of the sterilized herbal formula against mastitis-causing bacterial isolates was conducted. Tetracycline, erythromycin, and penicillin - common antibiotics for mastitis therapy in dairy farms - were used as standard antibiotics.
\end{abstract}

Results: Compared with autoclave sterilization, syringe filter sterilization resulted in less $(\mathrm{p}<0.05)$ phenolic and flavonoid contents. Against Escherichia coli and Staphylococcus aureus, the filter sterilized herbal formula (E. coli: $65.9 \%-73 \% ; S$. aureus: $6.2 \%-18.1 \%)$ markedly reduced the antibacterial activity than the autoclave-sterilized herbal formula $(E$. coli: $2.1 \%$ 3\%; S. aureus: $4.5 \%-10.7 \%$ ).

Conclusion: This study establishes that autoclave sterilization of the herbal formula is the best sterilization method that exerts minimal adverse effects on the phytochemical compounds and could sustain the antibacterial efficacy against mastitiscausing bacteria. Hence, the herbal formula could be used as an alternative treatment for bovine mastitis.

Keywords: herbal extract, mastitis, phytobiotic, phytochemical compound, sterilization method.

\section{Introduction}

Antibiotic residues in raw milk and milk products are a global health hazard. Recent years have witnessed several countries around the world implementing extensive bans on the use of antibiotics for livestock animals. Accordingly, the antimicrobial effects of plants have been extensively explored as an alternative to synthetic antibiotics. Ethnoveterinary medicine, which includes the use of medicinal plants, is regarded as an alternative to treat bovine mastitis, as well as prevent microbial resistance and antibiotic residues in milk. Recent research has demonstrated the efficacy of some herbs with antimicrobial, antifungal, anti-inflammation, and immunoreactive properties [1-4]. Research on dairy cows using herbs as feed additives reported a significant decline in the somatic

Copyright: Harjanti, et al. Open Access. This article is distributed under the terms of the Creative Commons Attribution 4.0 International License (http://creativecommons.org/licenses/ by/4.0/), which permits unrestricted use, distribution, and reproduction in any medium, provided you give appropriate credit to the original author(s) and the source, provide a link to the Creative Commons license, and indicate if changes were made. The Creative Commons Public Domain Dedication waiver (http:// creativecommons.org/publicdomain/zero/1.0/) applies to the data made available in this article, unless otherwise stated. cell count in milk, suggesting healing of inflammation in the mammary glands [5-9]. However, dietary herbal feed additive alone is insufficient to cure mammary inflammation in mastitis cases. To date, antibiotics remain the most effective method of curing mastitis.

Some preclinical studies determined the antimicrobial activities of herbs using several bioassays such as disk diffusion, well diffusion, broth agar, and agar dilution methods $[10,11]$. In addition, some previous studies successfully conducted the antibacterial susceptibility test of various single herbal extracts against mastitis-causing bacteria, which were isolated from mastitis milk [4]. The most persistent problem in preclinical studies is the contamination due to bacteria, fungus, and mold, which, perhaps, arises while executing stages of extraction and following experimental procedures. The standard method to sterilize herbal extract is filtrating using syringe microfiltration membrane [10]; however, the use of these membranes is energy consuming and expensive. Besides, preclinical studies further use of plant extract mixtures as herbal formulas in clinical studies and the commercialization of herbal antibiotics need sterile materials. In the pharmaceuticals industry, the safety of herbal medicines has 
been a concern since the commercialization of herbal products began. Regarding bovine mastitis, sterile antibiotic administration into the mammary gland through teat meatus (intramammary treatment) remains the most effective method to cure mastitis. Some widely applied sterilization methods in research and antibiotic manufacturing have been $0.45 \mu \mathrm{M}$ syringe filter membrane and gamma irradiation [12-14]. Of note, a good sterilization method must effectively eliminate microbes without damaging the bioactive compound. Besides the antibacterial efficacy, the method should be cost-effective so that it could be applied in experiments and the pharmaceuticals industry.

This study aimed to investigate two different sterilization methods and compare the concentration of bioactive compounds and the antibacterial activity after sterilization. The antibacterial efficacy was tested against mastitis-causing bacteria, which was isolated from mastitis-infected cows. Notably, tetracycline, erythromycin, and penicillin, which are commonly used for mastitis therapy in dairy farms $[4,15,16]$, were used as standard antibiotics in this study.

\section{Materials and Methods}

\section{Ethical approval}

Ethical approval was not necessary for this study.

\section{Study period and location}

This study was conducted during the period April to August 2019. The experiment was conducted at Microbiology Laboratory, Medical Faculty Diponegoro University, Indonesia.

\section{Plant extraction and formulation}

Plant materials were collected from Semarang regency, which is located in Central Java Province, Indonesia at $1200 \mathrm{~m}$ a.s.l. (above sea level). Plant materials were identified by Dr. Jumari, MSc. at Biology Department, Diponegoro University. All materials were dried and finely grounded into a powder. The maceration procedure for each material was conducted as described by Harjanti et al. [4]. P. betle leaves extract (PBE), C. domestica extract (CDE), and C. zanthorriza extract (CZE) obtained were formulated into the following three formulations: (i) Formula $\mathrm{A}(0.5 \mathrm{~g} \mathrm{PBE}+0.4 \mathrm{~g} \mathrm{CDE}+0.3 \mathrm{~g} \mathrm{CZE})$; (ii) formula $\mathrm{B}$ (0.6 g PBE + 0.3 g CDE + 0.3 g CZE); and (iii) formula $\mathrm{C}(0.7 \mathrm{~g} \mathrm{PBE}+0.2 \mathrm{~g} \mathrm{CDE}+0.3 \mathrm{~g}$ CZE) . Then, each formula was added with $1.2 \mathrm{~mL}$ polyethylene glycol, 1 $\mathrm{mL}$ glycerin, and $60 \mathrm{~mL}$ sterile aquadest on a hot plate magnetic stirrer at $60^{\circ} \mathrm{C}$ with the rotational speed of $500 \mathrm{rpm}$. After $20 \mathrm{~min}$, the mixtures were filtered using a filter paper (Whatman No. 41; Merck, Germany) into a sterile bottle and place the lid securely.

\section{Sterilization method}

We applied two sterilization methods - sterilization using $0.45 \mu \mathrm{M}$ sterile syringe filter (Axiva Biotech, India) and sterilization using an autoclave (HVE-50; Hirayama, Japan). Of note, filtration was performed using $0.45 \mu \mathrm{M}$ sterile syringe filter membrane, and the flow through was collected in a sterile bottle. For autoclaving, the extract formula was autoclaved at $121^{\circ} \mathrm{C}$ for $15 \mathrm{~min}$. The prepared sterile extracts were stored at $4{ }^{\circ} \mathrm{C}$ before testing.

\section{Mastitis bacteria preparation}

Gram-positive (Staphylococcus aureus) and Gram-negative (Escherichia coli) bacteria were isolated from mastitis-infected cows, which were reared in the local dairy farms in Central Java Province. The isolation procedure was performed as described by Harjanti et al. [17]. The bacteria were subcultured on house prepared $5 \%$ sheep blood agar (Oxoid ${ }^{\mathrm{TM}}$ Blood Agar Base CM0055).

\section{Antibacterial susceptibility testing}

We used $0.85 \% \mathrm{NaCl}$ to dilute the isolated colonies of $S$. aureus and E. coli until McFarland 0.5 turbidity was reached. Then, the solution of bacterial inoculum was swabbed onto Mueller-Hinton agar (MHA) plates (Oxoid $^{T M}$ Blood Agar Base CM0337). Next, a sterile blank paper disk (Oxoid ${ }^{\mathrm{TM}}$ CT0998B) was aseptically placed onto MHA. Then, $25 \mu \mathrm{L}$ of three tested extract formulas were transferred to each disk. For positive control, $30 \mu \mathrm{g}$ tetracycline (Oxoid ${ }^{\mathrm{TM}}$ CT0043B), $15 \mu \mathrm{g}$ erythromycin (Oxoid $\left.{ }^{\mathrm{TM}} \mathrm{CT} 0020\right)$, and $10 \mathrm{U}$ penicillin $\mathrm{G}$ (Oxoid ${ }^{\mathrm{TM}}$ CT0043B) were used. The plates were incubated at $37^{\circ} \mathrm{C}$ for $24 \mathrm{~h}$. We measured the inhibition zone diameter with a ruler in $\mathrm{mm}$, using the unaided eye with a black background as a contrast.

\section{Total flavonoid and phenolic compounds}

Using the aluminum chloride colorimetric method, we determined the total flavonoid content of each sterile extract formula, as described by Bag et al. [18]. Next, the total phenolics of each sterile extract formula were determined using the Folin-Ciocalteu reagent, as described by Ghasemzadeh et al. [19].

\section{Statistical analysis}

In this study, a completely randomized design with three replicates was used to compare the antibacterial affectivity of three formulas, as well as compare the different sterilization methods. In addition, means comparison was performed using Duncan's new multiple range test $(p<0.05)$. All statistical analyses were performed using SPSS version 9.1 (SPSS Inc, Chicago, Illinois, USA).

\section{Results}

\section{Phytochemical compounds of the herbal formula}

Tables- 1 and 2 present the effects of different sterilization methods on the concentrations of phenol and flavonoid in the herbal formula. Table-1 shows that total phenol in formulas $\mathrm{A}-\mathrm{C}$ sterilized using an autoclave did not differ markedly with those without sterilization (control). However, syringe filter sterilization for formulas $\mathrm{A}$ and $\mathrm{C}$ resulted in less phenolic concentration $(p<0.05)$ than control and autoclave-sterilized formula. In addition, filter sterilized formula B exhibited a numerically lower concentration of phenol compared with control and autoclave-sterilized 
formula. Regarding flavonoid, both sterilization methods deceased the flavonoid concentration in the herbal formula (Table-2); however, the reduction was far less with autoclaving. The flavonoid concentration in autoclave-sterilized formulas A-C was higher $(\mathrm{p}<0.05)$ than those sterilized with the syringe filter. Moreover, the percentage decrease of phenol and flavonoid concentrations in the herbal formula after autoclave sterilization was less $(p<0.05)$ than those sterilized using the syringe filter (Figure-1). The reduction of total phenol ranged $7.7 \%-11.2 \%$ using autoclave sterilization and $18.6 \%-23.1 \%$ using syringe filter sterilization. For total flavonoid, however, the reduction ranged $11.4 \%$ $13.0 \%$ with autoclave sterilization and $28.4 \%-34.3 \%$ with syringe filter sterilization.

\section{Antibacterial susceptibility test}

The antibacterial susceptibility tests were conducted for all herbal formulas against mastitis-causing bacterial isolates $-E$. coli and S. aureus (Table-3). The inhibitory zone's diameter against $E$. coli for formulas A-C without sterilization was $9.7,10$, and $10 \mathrm{~mm}$, respectively. In addition, we observed a variation in antibacterial activities of formulas A-C against $S$. aureus with diameter inhibitory zones at 22.3, 22.7, and $23.2 \mathrm{~mm}$, respectively. Of note, the use of filter sterilized herbal formula reduced the antibacterial activity against $E$. coli, compared with control (without sterilization). The reduction of the antibacterial activity against $E$. coli was $65.9 \%-73 \%$ for filter sterilized herbal formula (Figure-2). Remarkably, autoclaving the herbal formula resulted in a low reduction of the antibacterial activity $(2.1 \%-3 \%)$ compared with the control group. The antibacterial activity against S. aureus reduced to $6.2 \%-18.1 \%$ for filter sterilized formula and $4.5 \%-10.7 \%$ for autoclave-sterilized herbal formula, compared with the control group. In this study, penicillin was resistant to $E$. coli, whereas erythromycin and tetracycline were more susceptible.

Table-1: Phenol concentration (ppm) of herbal formula after sterilization with different method.

\begin{tabular}{lccc}
\hline Herbal formula & \multicolumn{3}{c}{ Sterilization method } \\
\cline { 2 - 4 } & $\begin{array}{c}\text { Extract without sterilization } \\
\text { (control) }\end{array}$ & $\begin{array}{c}\text { Extract sterilized with syringe } \\
\text { filter }\end{array}$ & $\begin{array}{c}\text { Extract sterilized with } \\
\text { autoclave }\end{array}$ \\
\hline Formula A & $2325.4 \pm 112.7^{\mathrm{a}}$ & $1858.7 \pm 38.9^{\mathrm{b}}$ & $2144.7 \pm 63.0^{\mathrm{a}}$ \\
Formula B & $2536.2 \pm 308.4$ & $1940.3 \pm 179.3$ & $2291.6 \pm 229.8$ \\
Formula C & $3021.6 \pm 177.0^{\mathrm{a}}$ & $2452.4 \pm 70.7^{\mathrm{b}}$ & $2682.5 \pm 145.0^{\mathrm{ab}}$ \\
\hline
\end{tabular}

Values are mean \pm SEM of triplicate tests; abdifferent superscripts in the same row are significantly different $(p<0.05)$; sterilization methods applied were sterilization using syringe filter $0.45 \mu \mathrm{M}$ and sterilization using autoclave at $121^{\circ} \mathrm{C}$ for $15 \mathrm{~min}$

Table-2: Flavonoid concentration (ppm) of herbal formula after sterilization with different method.

\begin{tabular}{lccc}
\hline Herbal formula & Sterilization method & \\
\cline { 2 - 4 } & $\begin{array}{c}\text { Extract without sterilization } \\
\text { (control) }\end{array}$ & $\begin{array}{c}\text { Extract sterilized with } \\
\text { syringe filter }\end{array}$ & $\begin{array}{c}\text { Extract sterilized with } \\
\text { autoclave }\end{array}$ \\
\hline Formula A & $819.4 \pm 13.5^{\mathrm{a}}$ & $586.2 \pm 26.0^{\mathrm{c}}$ & $725.8 \pm 16.5^{\mathrm{b}}$ \\
Formula B & $509.8 \pm 2.5^{\mathrm{a}}$ & $335.1 \pm 4.9^{\mathrm{c}}$ & $443.8 \pm 3.2^{\mathrm{b}}$ \\
Formula C & $523.7 \pm 19.7^{\mathrm{a}}$ & $348.3 \pm 24.1^{\mathrm{c}}$ & $461.1 \pm 4.3^{\mathrm{b}}$
\end{tabular}

Values are mean \pm SEM of triplicate tests; abc different superscripts in the same row are significantly different $(p<0.05)$; sterilization methods applied were sterilization using syringe filter $0.45 \mu \mathrm{M}$ and sterilization using autoclave at $121^{\circ} \mathrm{C}$ for $15 \mathrm{~min}$

Table-3: Antibacterial activity of herbal formula against mastitis bacteria in comparison with standard antibiotic.

\begin{tabular}{lccc}
\hline Sterilization Method & Herbal Formula & Mean inhibition zones (mm) of microorganism \\
\cline { 3 - 4 } & & Escherichia coli & Staphylococcus aureus \\
\hline Extract without & $\mathrm{A}$ & 9.7 & 22.3 \\
sterilization (control) & $\mathrm{B}$ & 10.0 & 22.7 \\
& $\mathrm{C}$ & 10.0 & 23.2 \\
Extract sterilized with & $\mathrm{A}$ & 3.3 & 19.7 \\
syringe filter & $\mathrm{B}$ & 3.3 & 21.3 \\
& $\mathrm{C}$ & 2.7 & 19.0 \\
Extract sterilized with & $\mathrm{A}$ & 9.5 & 20.7 \\
autoclave & $\mathrm{B}$ & 9.7 & 21.7 \\
Standard antibiotic & $\mathrm{C}$ & 9.7 & 20.7 \\
& TE-30 & 23.8 & 22.7 \\
\end{tabular}

Sterilization methods applied were sterilization using syringe filter $0.45 \mu \mathrm{M}$ and sterilization using autoclave at $121^{\circ} \mathrm{C}$ for $15 \min$ 


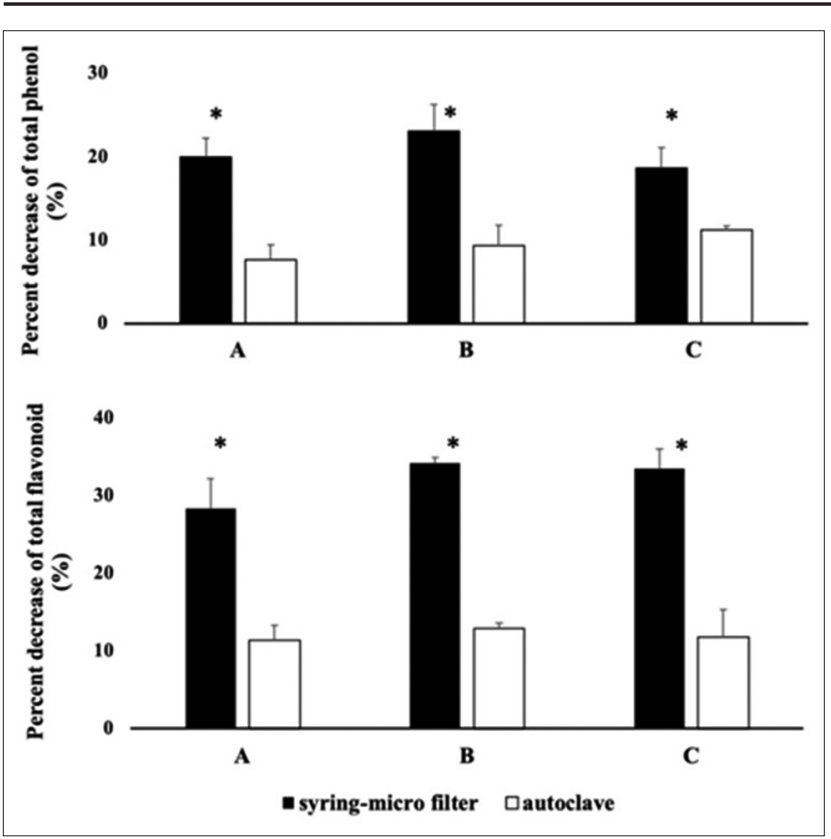

Figure-1: Comparison of percentage decrease of phenol and flavonoid concentrations after sterilization with syringe filter ( $\square$ ) and autoclave $(\square)$. * $(p<0.05)$. Sterilization methods applied were sterilization using syringe filter $0.45 \mu \mathrm{M}$ and sterilization using autoclave at $121^{\circ} \mathrm{C}$ for $15 \mathrm{~min}$

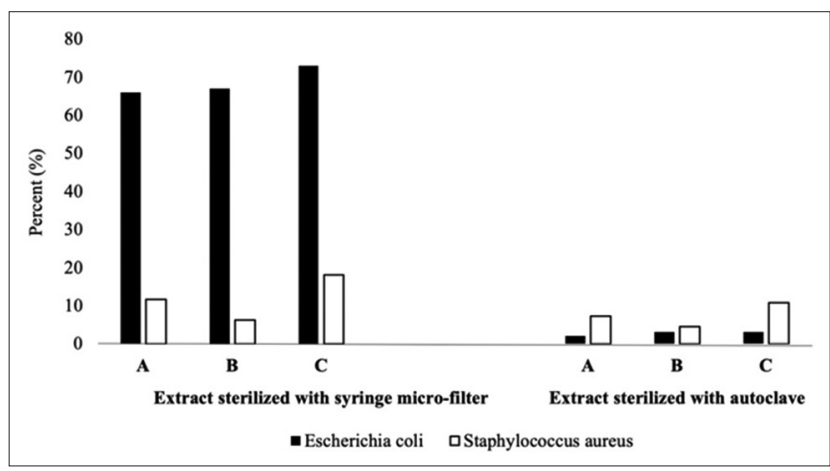

Figure-2: Comparison effect of different sterilization method on the percentage decrease of antibacterial activity against Escherichia coli (ם) and Staphylococcus aureus $(\square)$. Sterilization methods applied were sterilization using syringe filter $0.45 \mu \mathrm{M}$ and sterilization using autoclave at $121^{\circ} \mathrm{C}$ for $15 \mathrm{~min}$.

Regarding S. aureus, the inhibition zones obtained by all herbal formulas tested in this study were comparable with all standard antibiotics. Furthermore, the inhibition zones of standard antibiotics, tetracycline, erythromycin, and penicillin, for S. aureus were 22.7, 28.1 , and $21.1 \mathrm{~mm}$, respectively.

\section{Discussion}

Plants have a significant ability to synthesize secondary metabolites, which have recently been referred to as phytochemicals. Phenol and flavonoid are phytochemical compounds, which are naturally occurring and biologically active plant compound that has potential disease-inhibiting capabilities. In addition, phenol and flavonoid contents in plants reportedly exhibit antioxidant and antibacterial effects, as well as the immune system promoting and inflammatory effects [20]. Reportedly, phenol and flavonoid could be used to treat zoonotic diseases like mastitis [21-23]. Notably, understanding proper sterilization methods for preclinical research or clinical application is imperative to prevent huge damage and maximize the potential use of phytochemicals as an active compound in these herbs. Perhaps, thermal processing or sterilization method with high temperature could seriously damage the structure of bioactive compounds in extracts, which, in turn, decrease the antibacterial activity. Xu et al. [24] and Chaikham et al. [25] demonstrated that phytochemical compounds in herbal plants were decreased in quantity with thermal processing, and the reduction increased with increasing heating time. Likewise, a recent study illustrated that heat treatment had deleterious effects on phenolic concentrations of cauliflower and onion extracts [26]. Conversely, this study demonstrated that autoclave sterilization exerted a less negative impact on phenolic and flavonoid compounds, compared with the microfiltration method. To the best of our knowledge, no study has reported the effects of autoclave sterilization of herbal extract mixtures on the phytochemical compounds and antibacterial activity because it is believed that high temperature could adversely affect bioactive compounds. Indeed, several studies have used either a microfilter membrane or syringe microfilter membrane to sterilize herbal extracts [4,27-29]. Hashemi et al. [30] explored the effects of autoclaving various single aqueous extracts on the antibacterial activity. The difference with our study is that, for autoclaving, Hashemi et al. [30] impregnated the extract into a blank disk, which was then placed into a small glass bottle for sterilization using autoclave and only measured the antibacterial activity. We, however, prepared the mixed herbal formula and placed it into the bottle and then sterilized using an autoclave. The sterile formula packaged in the bottle is ready to use after sterilization. For the pharmaceutical industry, we believe that the method this study proposes is more applicable to phytoantibiotic manufacturing.

In the livestock industry, bovine mastitis plays a decisive role because of disturbing animal health, animal welfare, and causing substantial economic losses. Thus, antibiotic treatment is indispensable to maintain bovine udder health, animal welfare, and economic aspect in balance. Conversely, the emergence and spread of antibiotic resistance in milk is a pressing issue that could affect dairy product quality and human health. To date, several studies have explored the use of herbal remedies against bacterial isolates from mastitis-infected animals $[6,7,16,21]$. Reportedly, $S$. aureus and $E$. coli are the leading pathogens accountable for contagious mastitis in ruminants $[16,17,31]$. The effect of mastitis primarily depends on the etiology. The virulence factor influencing the bacteria pathogenicity in mastitis is the ability to form biofilm [32]. Bovine mastitis caused by both $S$. aureus and E. coli can range from being subclinical infection of the mammary gland 
to severe systemic disease $[15,16]$. Mastitis-causing $E$. coli bacteria are typically commensals [33]. Notably, $E$. coli incite strong inflammation through vigorous stimulation of cytokine synthesis, which, in turn, activate the local and general immune response of the host [34]. Nevertheless, evidence for the efficacy of antimicrobial treatment for E. coli mastitis is scarce [33]. Some previous studies suggested that $E$. coli isolates from mastitis have developed resistance to antimicrobials commonly used for dairy farms in years, including ampicillin, streptomycin, sulfonamides, and oxytetracycline $[33,35,36]$. This study reveals that $E$. coli was susceptible to erythromycin and tetracycline, but resistant to penicillin, whereas $S$. aureus was susceptible to all standard antibiotics (tetracycline, erythromycin, and penicillin). Likewise, this study demonstrated that S. aureus, Streptococcus agalactiae, and Streptococcus dysgalactiae are susceptible to penicillin and tetracycline, but E. coli is resistant to penicillin [35-37]. Some scholars recommend penicillin for the treatment of mastitis caused by Gram-positive pathogens $[23,31,36,37]$. Interestingly, in this study, all herbal formulas tested exhibited considerable growth-inhibiting activity against both $E$. coli and $S$. aureus, although the inhibition zones for Gram-negative E. coli were less than Gram-positive $S$. aureus. A similar pattern was observed in studies on bovine mastitis treatment using medicinal herbs $[22,38,39]$. Thus, some studies suggest that the difference in the susceptibility to antimicrobial agents between Gram-negative and Grampositive bacteria could correlate with the composition and structure of the cytoplasmic membrane and cell wall of bacteria $[34,40]$.

This study indicates the potential of the herbal extract to overcome both negative and positive bacterial infections and prevent resistance. The herbal formula possessed remarkable antibacterial activities because of the presence of phytochemical components, as biological or therapeutic activities of herbs closely correlate with their chemical components. In addition, $P$. betle leaves, $C$. domestica, and $C$. zanthorriza are medicinal plants that have been used as a folk medicine for a long time. Several studies have demonstrated that the antibacterial mechanism of phenolic compound correlates with their ability to modify the membrane permeability and affect the rigidity of cell wall, which induce the integrity losses $[40,41]$. Flavonoids possess a diverse range of pharmacological properties, including antibacterial and anti-inflammatory activities. The previous research has endeavored to determine whether the flavonoid activity is bacteriostatic or bactericidal by conducting time-kill studies and reported that flavonoid is not killing bacteria cells but merely inducing the formation of bacterial aggregates and thereby decreasing the bacteria number [41]. A recent study suggested that flavonoid did not inhibit bacterial growth but inhibited biofilm formation [42]. Reportedly, the biofilm formation is the pathogenicity virulence factor of bacteria [32].

\section{Conclusion}

This study establishes that sterilization of the herbal formula using an autoclave at $121^{\circ} \mathrm{C}$ for $15 \mathrm{~min}$ is the best method that exerts a less negative effect on the phytochemical compounds and could maintain the antibacterial efficacy against mastitis-causing bacteria. Hence, the herbal formula could be used as an alternative treatment for bovine mastitis.

\section{Authors' Contributions}

DWH designed, conducted the experiment, and prepared the manuscript. FW conducted the herbal formulation experiment and revised the manuscript. VRC conducted the microbiological experiment, data analysis and revised the manuscript. All authors read and approved the final manuscript.

\section{Acknowledgments}

The authors would like to thank the Ministry of Research, Technology and Higher Education, the Republic of Indonesia, for providing research grant (Grant number: 257-108/UN7.P4.3/PP/2019).

\section{Competing Interests}

The authors declare that they have no competing interests.

\section{Publisher's Note}

Veterinary World remains neutral with regard to jurisdictional claims in published institutional affiliation.

\section{References}

1. Agarwal, T., Singh, R., Shukla, A.D., Waris, I. and Gujrati, A. (2012) Comparative analysis of anibacterial activity of four Piper betel varieties. Adv. Appl. Sci. Res., 3(2): 698-705.

2. Dwivedi, V. and Tripathi, S. (2014) Review study on potential activity of Piper betle. J. Pharmacogenet. Phytochem., 3(4): 93-98.

3. Moghadamtousi, S.Z., Kadir, H.A., Hassandarvish, P., Tajik, H., Abubakar, S. and Zandi, K. (2014) A review on antibacterial, antiviral, and antifungal activity of curcumin. Biomed. Res. Int., 2014(1): 1-12.

4. Harjanti, D.W., Ciptaningtyas, R. and Wahyono, F. (2019) Phytochemical properties and antibacterial activity of Ageratum conyzoides, Piper betle, Muntinga calabura and Curcuma domestica against mastitis bacteria isolates. IOP Conf. Ser. Earth Environ. Sci., 247(1): 012049.

5. Nurdin, E., Amelia, T. and Makin, M. (2011) The effects of herbs on milk yield and milk quality of mastitis dairy cow. J. Indones. Trop. Anim. Agric., 36(2): 104-108.

6. Cigari, F.H., Khorvash, M., Ghorbani, G.R., Kadivar, M. and Riasi, A. (2014) Effects of supplementation with a phytobiotics-rich herbal mixture on performance, udder health, and metabolic status of Holstein cows with various levels of milk somatic cell counts. J. Dairy Sci., 97(12): 7487-7497.

7. Harjanti, D.W., Wahyono, F. and Afifah, D.N. (2019) Milk production and milk quality of sub-clinical mastitis cows feed with different supplementation of herbal in the diet. IOP Conf. Ser. Earth Environ. Sci. 250(1): 012062.

8. Mushtaq, S., Shah, A.M., Shah, A., Lone, S.A., Hussain, A., Hassan, Q.P. and Ali, M.N. (2018) Bovine mastitis: An appraisal of its alternative herbal cure. Microb. Pathog., 114(1): 357-361.

9. Salem, AY., El-Awady, H.G., El-Dein, M.A.T. and 
Eisa, D.A. (2019) Effect of supplementation of aromatic plants oils on immunity, udder health and milk production of Friesian cows. Slov. Vet. Res., 58(22): 523-530.

10. Punniamurthy, N., Ramakrishnan, N., Nair, M.N.B. and Vijayaraghavan, S. (2017) In vitro antimicrobial activity of ethnoveterinary herbal preparation for mastitis. Dairy Vet. Sci. J., 3(2): 1-2.

11. Liu, Q., Meng, X., Li, Y., Zhao, C.N., Tang, G.Y. and Li, H.B. (2017) Antibacterial and antifungal activities of spices. Int. J. Mol. Sci., 18(6): 1-62.

12. Kim, M.J., Yook, H.S. and Byun, M.W. (2000) Effects of gamma irradiation on microbial contamination and extraction yields of Korean medicinal herbs. Radiat. Phys. Chem., 57(1): 55-58.

13. Koseki, P.M., Villavicencio, A.L.V., Brito, M.S., Nahme, L.C., Sebastio, K.I., Almedia-Muradian, L.B., Mancini-Filho, J. and Freitas, P.C.D. (2002) Effects of irradiation in medicinal and eatable herbs. Radiat. Phys. Chem., 63(3-6): 681-684.

14. Sadava, D., Ahn, J., Zhan, M., Pang, M.L., Ding, J. and Kane, S.E. (2002) Effects of four Chinese herbal extracts on drug-sensitive and multidrug-resistant small-cell lung carcinoma cells. Cancer Chemother. Pharmacol., 49(4): 261-266.

15. Erskine, R.J., Walker, R.D., Bolin, C.A., Bartlett, P.C. and White, D.G. (2002) Trends in antibacterial susceptibility of mastitis pathogens during a seven-year period. J. Dairy Sci., 85(5): 1111-1118.

16. Saini, V., McClure, J.T., Scholl, D.T., DeVries, T.J. and Barkema, H.W. (2012) Herd-level association between antimicrobial use and antimicrobial resistance in bovine mastitis Staphylococcus aureus isolates on Canadian dairy farms. J. Dairy Sci., 95(4): 1921-1929.

17. Harjanti, D.W., Ciptaningtyas, R., Wahyono, F. and Setiatin, E.T. (2018) Isolation and identification of bacterial pathogen from mastitis milk in Central Java Indonesia. IOP Conf. Ser. Earth Environ. Sci., 102(1): 012076.

18. Bag, G.C., Devi, P.G. and Bhaigyabati, T. (2014) Assesment of total flavonoid content and antioxidant activity of methanolic extract of three Hedychium species of Manipur valley. J. Pharm. Sci. Res., 20(1): 154-159.

19. Ghasemzadeh, A., Jaafar, H.Z.E. and Rahmat, A. (2010) Antioxidant activities, total phenolics and flavonoids content in two varieties of Malaysia young ginger (Zinger officinale Roscoe). Molecules, 15(1): 4324-4333.

20. Tungmunnithum, D., Thongboonyou, A. and Yangsabai, A. (2018) Flavonoids and other phenolic compounds from medicinal plants for pharmaceutical and medical aspects: An overview. Medicines, 93(5): 1-16.

21. Cigari, F.H., Khorvash, M., Ghorbani, G.R., Kadivar, M., Riasi, A. and Zebeli, Q. (2014) Effects of supplementation with a phytobiotics-rich herbal mixture on performance, udder health, and metabolic status of Holstein cows with various levels of milk somatic cell counts. J. Dairy. Sci., 97(12): 7487-7497.

22. Zeedan, S.G., Abdalhamed, A.M., Abdeen, E., Ottai, M.E. and Shafy, S.A. (2014) Evaluation of antibacterial effect of some Sinai medicinal plant extracts on bacteria isolated from bovine mastitis. Vet. World, 7(11): 991-998.

23. Shin, B. and Park, W. (2018) Zoonotic disease and phytochemical medicines for microbial infections in veterinary science: Current state and future perspective. Front. Vet. Sci., 5(166): 1-9.

24. Xu, G., Ye, X., Chen, J. and Liu, D. (2007) Effect of heat treatment on the phenolic compounds and antioxidant capacity of citrus peel extract. J. Agric. Food Chem., 55(2): 330-335.

25. Chaikham, P., Worametrachanon S. and Apichartsrangkoon, A. (2014) Effects of high pressure and thermal processing on phytochemical, color and microbiological qualities of herbal-plant infusion. Int. Food Res. J., 21(1): 51-57.
26. Çubukçu, H.C., Kılıçaslan, N.S.D. and Durak, I. (2019) Different effects of heating and freezing treatments on the antioxidant properties of broccoli, cauliflower, garlic and onion. An experimental in vitro study. Sao Paulo Med. J., 137(5): 407-413.

27. Karaman, I., Sahin, F., Güllüce, M., Ögütçü, H., Sengül, M. and Adigüzel, A. (2003) Antimicrobial activity of aqueous and methanol extracts of Juniperus oxycedrus L. J. Ethnopharm., 85(2-3): 231-235.

28. Bakarnga, V.I., Yande, H.K., Kouipou, R.M.T., Kanko, M.I.M., Kammalac, A.J.M. and Boyom, FF. (2016) Effect of combined extracts from different plant parts of Annona senegalensis on antibacterial and antifungal activities. Int. J. Pharmacogn. Phytochem. Res., 8(1): 162-166.

29. Mostafa, A.A., Al-Askar, A.A., Almaary, K.S., Dawoud, T.M. and Bakri, M.M. (2018) Antimicrobial activity of some plant extracts against bacterial strains causing food poisoning diseases. Saudi J. Biol. Sci., 25(2): 361-366.

30. Hashemi, S.R., Zulkifli, I., Zunita, Z. and Somchit, M.N. (2008) The effect of selected sterilization methods on antibacterial activity of aqueous extract of herbal plants. J. Biol. Sci., 8(6): 1072-1076.

31. Leimbach, S. and Krömker, V. (2017) Mastitis treatment: Reduction in antibiotic usage in dairy cows. Reprod. Domest. Anim., 52(3): 21-29.

32. Vasudevan, P., Nair, M.K.M., Annamalai, T. and Venkitanarayanan, K.S. (2003) Phenotypic and genotypic characterization of bovine mastitis isolates of Staphylococcus aureus for biofilm formation. Vet. Microbiol., 92(1-2): 179-185.

33. Suojala, L., Kaarrtinen, L. and Pyörälä, S. (2013) Treatment for bovine Escherichia coli mastitis-an evidence-based approach. J. Vet. Pharm. Ther., 36(6): 532-521.

34. Günther, J., Petzl, W., Bauer, I., Ponsuksili, S., Zerbe, H., Schuberth, H.J., Brunner, R.M. and Seyfert, H.M. (2017) Differentiating Staphylococcus aureus from Escherichia coli mastitis: S. aureus triggers unbalanced immune-dampening and host cell invasion immediately after udder infection. Sci. Rep., 7(1): 4811-4817.

35. Cameron, A. and Mc-Allister, T.A. (2016) Antimicrobial usage and resistance in beef production. J. Anim. Sci. Biotech., 7(68): 1-22.

36. Pol, M. and Rueg, P.L. (2007) Relationship between antimicrobial drug usage and antimicrobial susceptibility of gram-positive mastitis pathogens. J. Dairy Sci., 90(1): 262-273.

37. Bengtsson, B., Unnerstad, H.E., Ekman, T., Artursson, K., Ost, M.N. and Waller, K.P. (2009) Antimicrobial susceptibility of udder pathogens from cases of acute clinical mastitis in dairy cows. Vet. Microbiol. 136(1-2): 142-149.

38. Klančnik, A., Piskernik, S., Jeršek, B. and Možina, S.S. (2010) Evaluation of diffusion and dilution methods to determine the antibacterial activity of plant extracts. $J$. Microbiol. Methods, 81(2): 121-126.

39. Abdalhamed, A.M., Zeedan, G.S.G. and Zeina, H.A.A. (2018) Isolation and identification of bacteria causing mastitis in small ruminants and their susceptibility to antibiotics, honey, essential oils, and plant extracts. Vet. World, 11(3): 355-362.

40. Chibane, L.B., Forquet, V., Lantéri, P., Clément, Y., Akkari, L.L., Oulahal, N., Degraeve, P. and Bordes, C. (2019) Antibacterial properties of polyphenols: Characterization and QSAR (quantitative structure-activity relationship) models. Front. Microbiol., 10(1): 829-833.

41. Cushnie, T.P. and Lamb, A.J. (2011) Recent advances in understanding the antibacterial properties of flavonoids. Int. J. Antimicrob. Agents, 38(2): 99-107.

42. Rodrigues, J.B.D., Junior, J.P.S. and de Souza, E.L. (2017) Inhibitory effects of flavonoids on biofilm formation by Staphylococcus aureus that overexpresses efflux protein genes. Microb. Pathog., 107(6): 193-197. 